\title{
Necrophagous Diptera associated with wild animal carcasses in southern Brazil
}

\author{
Ândrio Z. da Silva1 ${ }^{1}$, Camila H. Hoffmeister ${ }^{4}$, Vanessa A.dos Anjos ${ }^{5}$, Paulo B. Ribeiro ${ }^{3}$ \& Rodrigo F. Krüger ${ }^{2}$
}

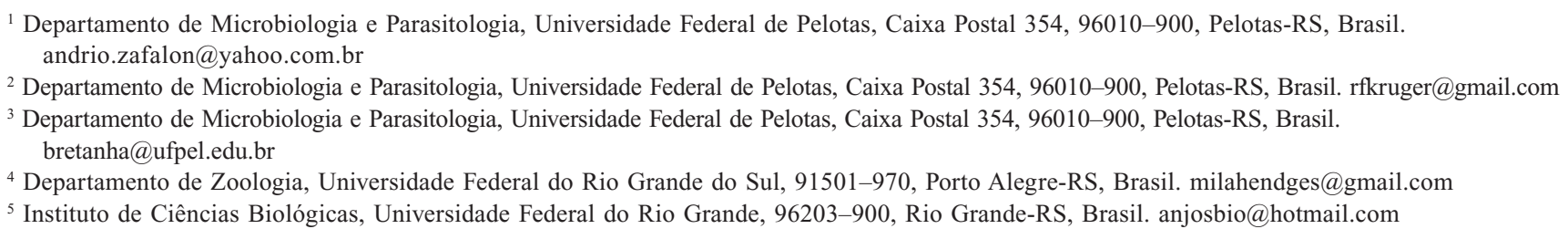

\begin{abstract}
Necrophagous Diptera associated with wild animal carcasses in southern Brazil. The aim of this study was to acquire a better knowledge concerning the diversity of necrophagous Diptera that develop on wild animal carcasses. For this purpose, the decomposition of six wild animal carcasses was observed in order to collect and identify the main species of necrophagous flies associated with the decomposition process. The carcasses were found on highways near the cities of Pelotas and Capão do Leão in the initial stage of decomposition, with no significant injuries or prior larval activity. Four wild animal models were represented in this study: two specimens of Didelphis albiventris Lund, 1840; two Tupinambis merianae Linnaeus, 1758; one Nothura maculosa Temminck, 1815; and one Cerdocyon thous Linnaeus, 1766. A total of 16,242 flies from 14 species were reared in the laboratory, where Muscidae presented the greatest diversity of necrophagous species. Overall, (i) carcasses with larger biomass developed a higher abundance of flies and (ii) the necrophagous community was dominated by Calliphoridae, two patterns that were predicted from published literature; and (iii) the highest diversity was observed on the smaller carcasses exposed to the lowest temperatures, a pattern that may have been caused by the absence of the generalist predator Chrysomya albiceps (Wiedemann, 1819). (iv) An UPGMA analysis revealed a similar pattern of clusters of fly communities, where the same species were structuring the groupings.
\end{abstract}

KEYWORDS. Calliphoridae; community, diversity; flies; Insecta.

Wild animal carcasses do not remain exposed to the environment for a long time because they are rapidly decomposed. Decomposition is a natural process that is important for ecosystem nutrient cycling (Hanski 1987). Among organisms that contribute to the biomass cycle, the order Diptera is highly important because it is the first to reach carcasses, where the adult stage will feed and oviposit minutes after an animal's death. In addition, the immature stages of many species use carcasses as a development site (Smith 1986). These biological characteristics make necrophagous Diptera important in applied sciences because they are vectors of pathogens that may cause myiasis and are useful in forensic entomology. Furthermore, knowledge of the ecological dynamics of necrophagous communities is very important to establish the role of necrophagous species in animal resources (Zumpt 1965; Greenberg 1971; Catts \& Goff 1992; Watson \& Carlton 2003; Byrd \& Castner 2010).

Thus, knowledge of necrophagous communities is often applied in forensic entomology, with pig carcasses being the animal model used in the majority of the studies. However, other animal models have been studied, such as chickens (Hall \& Dotsy 1993), rats (Monteiro-Filho \& Penereiro 1987), dogs (Johnson 1975), frogs and lizards (Cornaby 1974), rabbits (Souza et al. 2008), elephants (Smith 1986), bears (Anderson 1999; Watson \& Carlton 2003, 2005), and alligators
(Watson \& Carlton 2003, 2005). Thus, the diversity of animal models studied raises the following question: Can the use of non-traditional forensic models (different classes: Mammalia, Aves, Reptilia) influence the diversity of necrophagous Diptera?

Considering the variety of models, one hypothesis is that the diversity of necrophagous insects found may be influenced by the histological constitution of the carcasses used. Therefore, the aim of the present study was to contribute to a clearer understanding of the necrophagous Diptera diversity that develops on wild animal carcasses in southern Brazil.

\section{MATERIAL AND METHODS}

The field site of exposure was located in a semi-urban area $\left(31^{\circ} 48^{\prime} 00.31^{\prime \prime} \mathrm{S}, 52^{\circ} 25^{\prime} 04.66^{\prime \prime} \mathrm{W}\right)$ of the town Capão do Leão, and is characterized by pasture with grasses, herbs, and shrubs surrounded by woods of Eucalyptus spp.

Six carcasses were collected on the highways BR-392 and BR-116 near the access road to UFPel (Universidade Federal de Pelotas) and were donated to the Laboratory of Insect Biology and Taxonomy. These carcasses were two white-eared opossums, Didelphis albiventris Lund, 1840 (Mammalia, Didelphidae), weighing $0.68 \mathrm{~kg}$ (exposed in June 2008) and $3.00 \mathrm{~kg}$ (November 2009); two lizards, Tupinambis merianae 
Linnaeus, 1758 (Reptilia, Teiidae), weighing $1.56 \mathrm{~kg}$ (November 2009) and $1.69 \mathrm{~kg}$ (December 2008); one spotted nothura, Nothura maculosa Temminck, 1815 (Aves, Tinamidae) weighing $0.29 \mathrm{~kg}$ (September 2008); and one crab-eating fox, Cerdocyon thous Linnaeus, 1766 (Mammalia, Canidae), weighing $5.60 \mathrm{~kg}$ (November 2009). All models used in the experiments arrived at the laboratory in the early stages of decomposition, apparently intact, and without serious injuries or prior larval activity. The white-eared opossum (November 2009) arrived frozen at the laboratory and had external bruises in the mandibular region. The lizard (November 2009) was the only model with major body deformations such as dorsoventral flatness in the posterior region around the hind legs and tail, probably caused by being run over by a car.

In order to allow environmental exposure, the carcasses were kept in a metal cage measuring $90 \times 70 \times 45 \mathrm{~cm}$ (width $\times$ length $\times$ depth) to exclude vertebrate necrophagous activity. In the center of the cage, a tray with moderately moist sawdust was placed where the carcass was exposed to collect the immature specimens that abandoned it. The average monthly temperatures of the field site of exposure were obtained from online newsletters of the regional agroclimatic station, published by the Brazilian Corporation of Agricultural Research (Embrapa 2012).

The carcasses were observed daily to collect immature specimens that abandoned the substrate. At the beginning of the dry season, the carcasses were transferred to the laboratory to collect the remaining immature specimens. The immature specimens were conditioned in jars with moist sawdust and covered by gauze to allow air intake and the retention of adults after emergence. The jars were kept at a controlled temperature $\left(25^{\circ} \mathrm{C} \pm 2{ }^{\circ} \mathrm{C}\right)$, relative air humidity greater than $70 \%$, and a 12 -hour photophase.

The emerged adult insects were killed and preserved in $70 \%$ alcohol for later identification. The adult dipteran identification followed the taxonomic keys of Carvalho \& Ribeiro (2000), Carvalho (2002), Carvalho \& Mello-Patiu (2008), Wendt \& Carvalho (2009), and Vairo et al. (2011). The voucher specimens were deposited in the Diptera collection of the Laboratory of Parasite and Vectors Ecology (UFPel) and in the Padre Jesus Santiago Moure entomological collection of the Federal University of Parana (UFPR).

An agglomerative hierarchical classification multivariate analysis with UPGMA (Unweight Pair-Groups Method using Arithmetic Averages) was used to verify the relationship between the dipteran communities among carcasses models and the connection between dipteran communities among times of year using the dissimilarity coefficient of Bray-Curtis such as in Sneath \& Sokal (1973).

The statistical software R (R Development Core Team 2013) with vegan and stats packages was used for the analysis of the co-relationship matrix with the vegdist function and the dissimilarity between the groups with the hclust function (Borcard et al. 2011). A so-called heatmap analysis was also applied to the Spearman correlation matrix. A heatmap is a two-dimensional visualization technique for high-dimen- sional data originally used in genetics (Eisen et al. 1998, Hastie et al. 2009). In this graphical presentation of data, numerical values are displayed by colors. The heatmap also re-arranges the rows and columns of the data so that similar rows and similar columns are grouped, with their similarity represented by a dendrogram with Bray-Curtis dissimilarity. The heatmap was conducted in $\mathrm{R}$ with the function heatmap. 2 from the gplots package. The rows and columns were reordered by dendrograms derived from hierarchical clustering. Due to the symmetry of the input data, rows and columns were rearranged in the same order.

\section{RESULTS}

A total of 16,242 adult specimens of 14 species (Table II) were reared from the six carcasses (Table I). The relationship between vertebrate carcass mass and the abundance of specimens was directly proportional except for one lizard model (Table I), which had few Diptera specimens. The number of species varied according to the carcass model, and the greatest number of species was observed in the opossum weighing $0.68 \mathrm{~kg}$ that had been exposed to the lowest average temperature registered $\left(12.7^{\circ} \mathrm{C}\right)$.

Table I. Relationship among wildlife vertebrate carcasses mass, biomass, expositional period (month/year) and average monthly temperature to the total abundance of Diptera specimens collected in Pelotas, Rio Grande do Sul, Brazil.

\begin{tabular}{lcccc}
\hline \multicolumn{1}{c}{ Vertebrate carcass } & Biomass & Month/Year & $\begin{array}{c}\text { Average } \\
\text { Temperature }\end{array}$ & $\begin{array}{c}\text { Total } \\
\text { Abundance }\end{array}$ \\
\hline Cerdocyon thous $(\mathrm{C} 1)$ & $5.60 \mathrm{Kg}$ & Dec $/ 09$ & $21.6^{\circ} \mathrm{C}$ & 8,583 \\
Didelphis albiventris (D1) & $0.69 \mathrm{Kg}$ & $\mathrm{Jun} / 08$ & $12.7^{\circ} \mathrm{C}$ & 2,273 \\
Didelphis albiventris (D2) & $3.00 \mathrm{Kg}$ & $\mathrm{Nov} / 09$ & $21.6^{\circ} \mathrm{C}$ & 3,383 \\
Nothura maculosa $(\mathrm{N} 1)$ & $0.29 \mathrm{Kg}$ & $\mathrm{Sep} / 09$ & $15.0^{\circ} \mathrm{C}$ & 1,267 \\
Tupinambis merianae (T1) & $1.56 \mathrm{Kg}$ & Nov $/ 09$ & $21.6^{\circ} \mathrm{C}$ & 563 \\
Tupinambis merianae (T2) & $1.69 \mathrm{Kg}$ & Dec $/ 08$ & $22.6^{\circ} \mathrm{C}$ & 173 \\
\hline
\end{tabular}

The four Diptera families were present in all carcasses, except for Sarcophagidae, which was not observed in the opossum from November 2009. Table II shows the abundance of necrophagous species reared on vertebrate carcasses, where Calliphoridae was the most frequent family found, followed by Sarcophagidae, Muscidae, and Fanniidae.

The Calliphoridae species Chrysomya albiceps (Wiedemann, 1819), Hemilucilia semidiaphana (Rondani, 1850), and Lucilia eximia (Wiedemann, 1819) were numerically dominant, representing $92.8 \%$ of Diptera collected in this study. The blowfly $C$. albiceps occurred exclusively on the crab-eating fox from December 2009 and the opossum from November 2009. These carcasses shared two variables: (i) a mass greater than $3.00 \mathrm{~kg}$ and (ii) the same average temperature during exposure $\left(21.6^{\circ} \mathrm{C}\right)$ (Figs. 1, 2). Hemilucilia semidiaphana predominated in carcasses below $3 \mathrm{~kg}$ and $L$. eximia in carcasses below $1 \mathrm{~kg}$. These associations favored the clusters observed (Fig. 1).

The second most abundant family was Sarcophagidae, surpassing Calliphoridae only in the lizard from December 

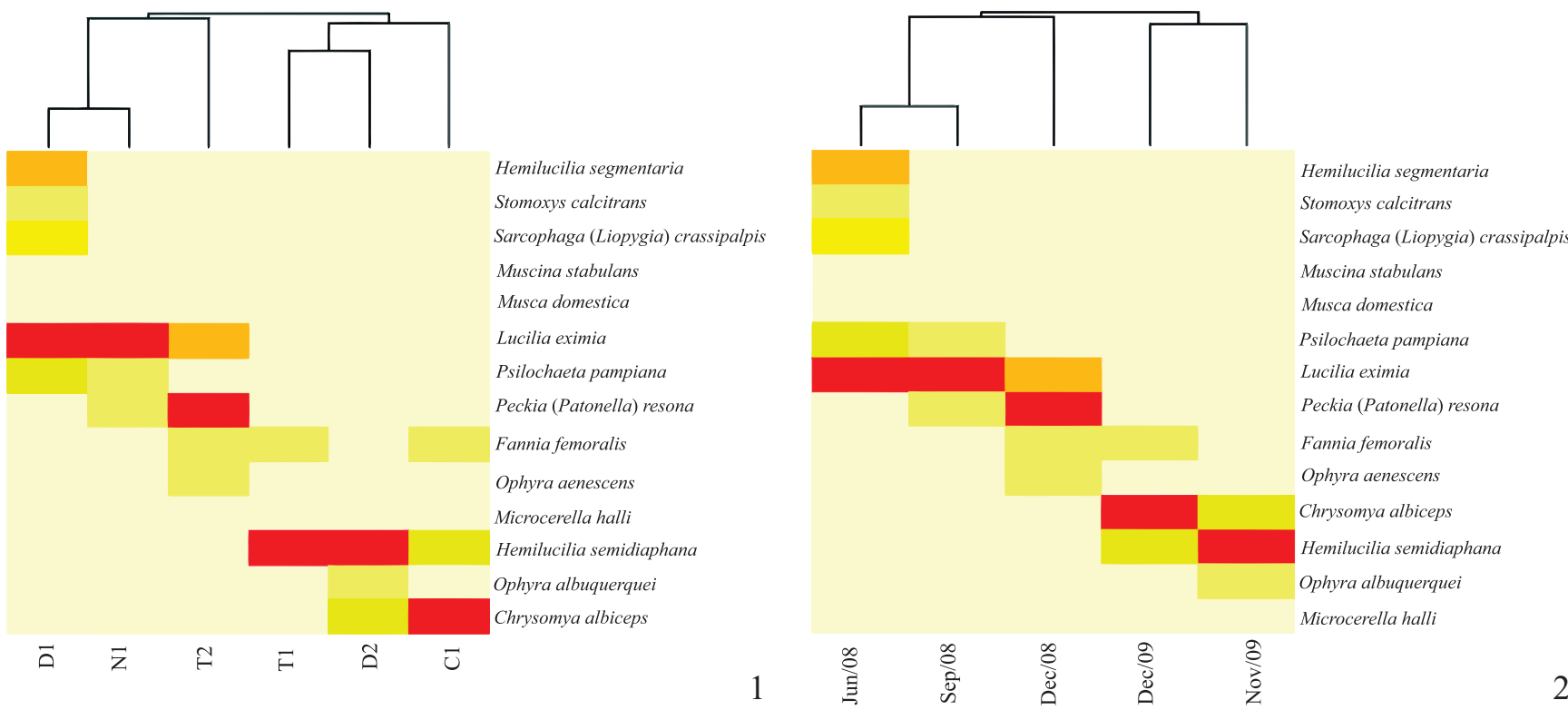

Figs 1-2. Heatmaps. 1. Heatmap showing abundances within the 14 species among the carcasses communities. The species heatmap displays raw species counts per carcass, where the counts are colored based on the contribution of each species to the total species count present in that carcass, weak colored shades indicates contributions with low percentage of species to sample, whereas strong colored shades contributes for a high percentage of species. D1, Didelphis albiventris (Mammalia, Didelphidae), weighing $0.68 \mathrm{~kg}$; D2, Didelphis albiventris, weighing $3.00 \mathrm{~kg}$; T1, Tupinambis merianae (Reptilia, Teiidae), weighing $1.56 \mathrm{~kg}$; T2, Tupinambis merianae, weighing $1.69 \mathrm{~kg}$; N1, Nothura maculosa (Aves, Tinamidae) weighing $0.29 \mathrm{~kg}$; C1 Cerdocyon thous (Mammalia, Canidae) weighing $5.60 \mathrm{~kg}$. 2. Heatmap showing abundances within the 14 species among the carcasses exposure month of the year. The species heatmap displays raw species counts per carcass, where the counts are colored based on the contribution of each species to the total species count present in that carcass, weak colored shades indicates contributions with low percentage of species to sample, whereas strong colored shades contributes for a high percentage of species.

Table II. Necrophagous Diptera species and their abundance in vertebrates carcasses, in Pelotas, Rio Grande do Sul, Brazil. See Table I for codes of carcasses.

\begin{tabular}{|c|c|c|c|c|c|c|}
\hline \multirow{2}{*}{ Diptera } & \multicolumn{6}{|c|}{ Vertebrate carcasses } \\
\hline & $\mathrm{C} 1$ & D1 & D2 & $\mathrm{N} 1$ & $\mathrm{~T} 1$ & $\mathrm{~T} 2$ \\
\hline \multicolumn{7}{|l|}{ Calliphoridae } \\
\hline Chrysomya albiceps (Wiedemann, 1819) & 8177 & 0 & 237 & 0 & 0 & 0 \\
\hline Hemilucilia segmentaria (Fabricius, 1805) & 0 & 401 & 0 & 0 & 0 & 0 \\
\hline Hemilucilia semidiaphana (Rondani, 1850) & 307 & 0 & 3057 & 0 & 541 & 0 \\
\hline Lucilia eximia (Wiedemann, 1819) & 0 & 1473 & 0 & 1230 & 0 & 40 \\
\hline \multicolumn{7}{|l|}{ Fanniidae } \\
\hline Fannia femoralis (Stein, 1897) & 64 & 6 & 1 & 1 & 12 & 3 \\
\hline \multicolumn{7}{|l|}{ Muscidae } \\
\hline Musca domestica Linnaeus, 1758 & 0 & 2 & 0 & 1 & 0 & 0 \\
\hline Muscina stabulans (Fallén, 1817) & 0 & 9 & 0 & 1 & 0 & 0 \\
\hline Ophyra aenescens (Wiedemann, 1830) & 33 & 0 & 0 & 0 & 3 & 4 \\
\hline Ophyra albuquerquei Lopes, 1985 & 0 & 0 & 88 & 0 & 2 & 0 \\
\hline Psilochaeta pampiana (Shannon \& Del Ponte, 1926) & 0 & 65 & 0 & 24 & 2 & 0 \\
\hline Stomoxys calcitrans (Linnaeus, 1758) & 0 & 50 & 0 & 0 & 0 & 0 \\
\hline \multicolumn{7}{|l|}{ Sarcophagidae } \\
\hline Microcerella halli (Engel, 1931) & 0 & 0 & 0 & 0 & 2 & 0 \\
\hline Peckia (Patonella) resona (Lopes, 1935) & 2 & 0 & 0 & 10 & 1 & 126 \\
\hline Sarcophaga (Liopygia) crassipalpis (Macquart, 1839) & 0 & 267 & 0 & 0 & 0 & 0 \\
\hline
\end{tabular}

2008. Microcerella halli (Engel, 1931) was observed exclusively in the lizard from November 2009, with two specimens. Sarcophaga (Liopygia) crassipalpis (Macquart, 1839) was observed only in the opossum from June 2008, with an abundance of 267 specimens. Peckia (Patonella) resona (Lopes, 1935) occurred in multiple carcasses at distinct abun- dances: two specimens in the crab-eating fox, 10 in the spotted nothura, one in the lizard from November 2009, and 126 from the other lizard (December 2008).

Muscidae was the most diverse family, predominantly species with facultative predatory larvae in the third instar. Ophyra aenescens (Wiedemann, 1830) and O. albuquerquei Lopes, 
1985 were observed in the crab-eating fox, the opossum from November 2009, and both lizards (December 2008 and November 2009). The most abundant Muscidae was Psilochaeta pampiana (Shannon \& Del Ponte, 1926), with 65 specimens in the opossum from June 2008, 24 specimens in the spotted nothura, and two specimens in the lizard from November 2009. The house fly Musca domestica (Linnaeus, 1758) was reared in the opossum from June 2008 and the spotted nothura, the two smaller carcasses exposed to the lowest temperatures (Table I). Two specimens of $M$. domestica completed their development, one in the opossum from June 2008 and the other in the spotted nothura. The false stable fly Muscina stabulans (Fallén, 1817) was found 10 times: nine adults in the opossum from June 2008 and one in the spotted nothura. There were 50 specimens of Stomoxys calcitrans (Linnaeus, 1758) found exclusively in opossum from June 2008, where they were the second most abundant Muscidae in the carcass.

Fanniidae was reared in lower abundances, F. femoralis being the only species represented in the present study, although it was found in all carcasses.

\section{DISCUSSION}

Carcasses with larger biomass developed a higher abundance of flies, as predicted by other authors (Moura et al. 2005; Simmons et al. 2010), except for the lizard carcasses. In ephemeral substrates, the majority of species occur at low density, presenting few species with elevated abundance, which is a common pattern in nature (Preston 1962). The communities were dominated by species with low competitiveness, except $C$. albiceps in carcasses with a biomass above $1 \mathrm{~kg}$ (Moura et al. 2005; Salazar 2006; Souza et al. 2008), where this species was a very good competitor. There was also no relationship between the size of the carcass and the structure of the necrophagous insect community (Moura et al. 2005). Differences in the structure of these communities in ephemeral resources are probably attributable to seasonal variations in temperature and relative humidity (Campobasso et al. 2001) (Fig. 2).

However, two consistent patterns of occurrence have been observed for some species of necrophagous flies in southern Brazil, the first being the pattern of synchronic behavior between $C$. albiceps and L. eximia. The blowfly L. eximia shows a regular occurrence during the whole year; however, in cold seasons $C$. albiceps visits carcasses only at a low abundance (Souza et al. 2008). When the temperature rises above $20^{\circ} \mathrm{C}$ there is an increase in the abundance of $C$. albiceps and a reduction or disappearance of $L$. eximia from ephemeral resources (Vianna et al. 2004; Souza et al. 2008; Azevedo \& Krüger 2013). The coexistence of both species did not occur, probably because $L$. eximia presents generalist behavior in the exploitation of organic matter in decomposition. On the other hand, C. albiceps demonstrates facultative predation behavior over other Diptera larvae that are not specialized in resource exploitation, such as L. eximia, causing competitive exclusion (Faria et al. 2004).
The second pattern is the occurrence of species of Muscidae that are facultative predators of third-instar larvae (Skidmore 1985). In ephemeral resources, it is common to find these species in the process of intraguild competition, particularly when resources are scarce (Revilla 2002; Duarte et al. 2013). Muscidae species that occurred in this study exhibited this behavior. However, they differed in their temperature and relative humidity requirements. While $O$. aenescens and $O$. albuquerquei occurred in carcasses exposed to temperatures above $21^{\circ} \mathrm{C}$, as observed by Ribeiro et al. (2000), M. stabulans occurred on substrates that were exposed to lower temperatures (Souza et al. 2008). Similar to species of Ophyra Robinneau-Desvoidy, 1930 and $M$. stabulans, Psilochaeta pampiana has facultative predatory behavior. Although $P$. pampiana was considered only a rat carcass visitant in other studies (Moura et al. 1997), in the present study it developed in three different models (Table II), and these represent new records of this species developing in carcasses, at least in the Pelotas region.

The Sarcophagidae species $M$. halli developed in the reptile carcass from November 2009 and was also observed in other studies, such as snake carrion (Bothrops alternatus Duméril, Bibron \& Duméril, 1854) (Moretti et al. 2009), small rodents (Moretti et al. 2008), and rabbits (Vairo et al. 2011). These facts about $M$. halli are in agreement with those discussed by Moretti et al. (2009) for the data of Kneidel (1984), stating that many species reared on small carcasses of non-mammals are apparently opportunistic users of a wide variety of organic substances in decomposition, as commonly observed in other generalist necrophagous species. Other Sarcophagidae species, such as $S$. (L.) crassipalpis and $P$. $(P$.) resona, have also been observed in others carcasses (Nishida 1984; Monteiro-Filho \& Peneireiro 1987; Moura et al. 1997), including in the Pelotas region (Krüger et al. 2003; Souza et al. 2008).

Fanniidae was previously reported in carcasses in other studies, and adult emergence from the carcass is usually noticed at low abundances (Carvalho et al. 2000; Souza \& Linhares 1997). This pattern is probably caused by the pressure of other competing dipteran larvae on Fanniidae larvae, and only a small part of the population manages to avoid predation and develop to the adult stage. In this study, $F$. femoralis was the only Fanniidae found. It presented generalist behavior in its exploitation of resources due to its development in all carcass models, and it was found in carcasses exposed to both high and low temperatures. Fannia femoralis was observed in other carcass experiments, presenting a similar aseasonal pattern of occurrence as in our results (Aballay et al. 2012; Horenstein et al. 2010; Moura et al. 2005).

This study contributes to our knowledge of the necrophagous fauna associated with wild animals, allowing us to infer that the most important factors in structuring necrophagous communities are environmental factors such as climatic conditions (seasonality) and the site of carcass site exposure rather than the species of animal carcass. These patterns may be evidenced by the well-known biological characteristics of 
necrophagous species and by the clusters of similarity (UPGMA analysis; Figs. 1, 2) regarding the similar structuring pattern of dipteran communities independent of the carcass model.

\section{ACKNOWLEDGMENTS}

We thank Prof. Dra. Gertrud Müller Antunes and Biol. Virgiane Lima Knorr for the donation of wildlife animals; Dr. Thiago de Carvalho Moretti, M.Sc. Juliano Lessa Pinto Duarte and Richard Floriani Emmerich for critical reading and suggestions to this manuscript.

\section{REFERENCES}

Aballay, F.H., Domínguez, M.C. \& Campón, F.F. 2012. Adult Fanniidae associated to pig carcasses during the winter season in a semiarid environment: Initial examination of their potential as complementary PMI indicators. Forensic Science International 219: 284.e1-284.e4.

Anderson, G.S. 1999. Wildlife forensic entomology: determining time of death in two illegally killed black bear cubs. Journal of Forensic Science 44: 856-859.

Azevedo, R. R. \& Krüger, R.F. 2013. The influence of temperature and humidity on abundance and richness of Calliphoridae (Diptera). Iheringia, série Zoologia 103: 145-152.

Borcard, D., Gillet, F. \& Legendre, P. 2011. Numerical Ecology with R. New York, Springer, xii+306 p.

Byrd, J.H. \& Castner J.L. 2010. Forensic entomology: the utility of arthropods in legal investigations. 2nd ed. Boca Raton, CRC Press, $440 \mathrm{p}$.

Campobasso, C. P., Vella, G. \& Introna, F. 2001. Factors affecting decomposition and Diptera colonization. Forensic Science International 120: 18-27.

Carvalho, C.J.B. 2002. Muscidae (Diptera) of the Neotropical Region: Taxonomy. Curitiba, Ed. UFPR, 288 p.

Carvalho, C.J.B. \& Mello-Patiu, C.A. 2008. Key to adults of the most common forensic species of Diptera in South America. Revista Brasileira de Entomologia. 52: 390-406.

Carvalho, C.J.B. \& Ribeiro, P.B. 2000. Chave de identificação das espécies de Calliphoridae (Diptera) do sul do Brasil. Revista Brasileira de Parasitologia Veterinária 9: 169-173.

Carvalho, L.M.L., Thyssen, P.J., Linhares, A.X. \& Palhares, F.A.B. 2000. A checklist of arthropods associated with pig carrion and human corpses in southeastern Brazil. Memórias do Instituto Oswaldo Cruz 95: $135-138$.

Catts, E.P. \& Goff, M.L. 1992. Forensic entomology in criminal investigations. Annual Review of Entomology 37: 253-272.

Cornaby, B.W. 1974. Carrion reduction by animals in constrasting tropical habitats. Biotropica 6: 51-63.

Duarte, J.L.P., Krüger, R.F. \& Ribeiro, P.B. 2013. Interaction between Musca domestica L. and its predator Muscina stabulans (Fallén) (Diptera, Muscidae): Effects of prey density and food source abundance. Revista Brasileira de Entomologia 57: 55-58.

Eisen, M.B., Spellman, P.T., Brown, P.O. \& Botstein, D. 1998.Cluster analysis and display of genome-wide expression patterns. Proceedings of the National Academy of Sciences of the United States of America 95: 14863-14868.

Embrapa Clima Temperado 2012. Agroclimatic Newsletters. Available at: http://www.cpact.embrapa.br/agromet/estacao/boletim.php (accessed 15 September 2012).

Faria, L.D.B., Godoy, W.A.C. \& Reis, S.F. 2004. Larval predation on different instars in blowfly populations. Brazilian Archives of Biology and Technology 47: 887-894.

Greenberg, B. 1971. Flies and disease: I. Ecology, classification and biotic associations. New Jersey, Princeton University Press, 856 p.
Hall, R.D. \& Dotsy, K.E. 1993. Length of time after death: Effect on attraction and oviposition or larviposition of midsummer blowflies (Diptera, Calliphoriadae) and the flesh flies (Diptera, Sarcophagidae) of medicolegal importance in Missouri. Annals of the Entomological Society of America 86: 589-593.

Hanski, I. 1987. Carrion fly community dynamics: patchiness, seasonality and coexistence. Ecological Entomology 12: 257-266.

Hastie, T., Tibshirani, R. \& Friedman, J. 2009. The Elements of Statistical Learning. Data Mining, Inference, and Prediction. New York, Springer, xxii+745 p.

Horenstein, M.B., Linhares, A.X., De Ferradas, B.R. \& García, D. 2010. Decomposition and dipteran succession in pig carrion in central Argentina: ecological aspects and their importance in forensic science. Medical and Veterinary Entomology 24: 16-25.

Johnson, M.D. 1975. Seasonal and microseral variations in the insect populations on carrion. American Midland Naturalist 93: 79-90.

Kneidel, K.A. 1984. Competition and disturbance in communities of carrion-breeding Diptera. Journal of Animal Ecology 53: 849-865.

Krüger, R.F., Ribeiro, P.B. \& Costa, P.R.P. 2003. Ciclo de vida de Sarcophaga (Liopygia) crassipalpis (Macquart) (Diptera, Sarcophagidae). Entomologia y Vectores 10: 85-98.

Monteiro-Filho, E.L.A. \& Penereiro, J.L. 1987. Estudo de decomposição e sucessão sobre uma carcaça animal numa área do estado de São Paulo, Brasil. Revista Brasileira de Biologia 47: 289-295.

Moretti, T.C., Allegretti, S.M., Mello-Patiu, C.A., Tognolo, A.M., Ribeiro, O.B. \& Solis, D.R. 2009. Occurrence of Microcerella halli (Engel) (Diptera, Sarcophagidae) in snake carrion in southeastern Brazil. Revista Brasileira de Entomologia 53: 318-320.

Moretti, T.C., Ribeiro, O.B., Thyssen, P.J. \& Solis, D.R. 2008. Insects on decomposing carcasses of small rodents in a secondary forest in southeastern Brazil. European Journal of Entomology 105: 691696.

Moura, M.O., Carvalho, C.J.B., \& Monteiro-Filho, E.L.A. 1997. A preliminary analysis of insects of medico-legal importance in Curitiba, state of Paraná. Memórias do Instituto Oswaldo Cruz 92: 269-274.

Moura, M.O., Carvalho, C.J.B. de \& Monteiro-Filho, E.L.A. 2005. Estrutura de comunidades necrófagas: efeito da partilha de recursos na diversidade. Revista Brasileira de Zoologia 22: 1134-1140.

Nishida, K. 1984. Experimental studies on the estimation of postmortem intervals by means of fly larvae infesting human cadavers. Japanese Journal of Legal Medicine 38: 24-41.

Preston, F.W. 1962. The canonical distribution of commonness and rarity: Part I. Ecology 43: 185-215.

R Development Core Team 2013. R: A Language and environment for statistical computing. Vienna, R Foundation for Statistical Computing. Available at: http://www.R-project.org (accessed 28 September 2013).

Revilla, T. 2002. Effects of effects of intraguild predation on resource competition. Journal of Theoretical Biology 214: 49-62.

Ribeiro, P.B., Carvalho, C.J.B., Pinto, L. \& Silveira Jr., P. 2000. Flutuação populacional das espécies de Ophyra Robineau-Desvoidy (Diptera, Muscidae, Azeliinae), em Pelotas, RS. Arquivos do Instituto Biológico 67: 205-214.

Salazar, J.L. 2006. Insectos de importancia forense en cadáveres de ratas, Carabobo - Venezuela. Revista Peruana de Medicina Experimental y Salud Publica 23: 33-38.

Simmons, T., Adlam, R.E., \& Moffatt, C. 2010. Debugging decomposition data-comparative taphonomic studies and the influence of insects and carcass size on decomposition rate. Journal of Forensic Science 55 : $8-13$.

Skidmore, P. 1985. The biology of the Muscidae of the world. Series Entomologica, volume 29. Dordrecht, Springer Science \& Business Media, xiv $+550 \mathrm{p}$.

Smith, K.G.V. 1986. A Manual of Forensic Entomology. London, British Museum (Natural History) \& Ithaca, Cornell University Press, 205 p.

Sneath, P.H.A. \& Sokal, R.R. 1973. Numerical taxonomy: The principles and practice of numerical classification. San Francisco, W. H. Freeman \& Co., xvi+573 p. 
Souza, A.S.B., Kirst, F.D. \& Krüger, R.F. 2008. Insects of forensic importance from Rio Grande do Sul state in southern Brazil. Revista Brasileira de Entomologia 52: 641-646.

Souza, A.M. \& Linhares, A.X. 1997. Diptera and Coleoptera of potential forensic importance in southeastern Brazil: relative abundance and seasonality. Medical and Veterinary Entomology 11: 8-12.

Vairo, K.P., Mello-Patiu, C.A. \& Carvalho, C.J.B. 2011. Pictorial identification key for species of Sarcophagidae (Diptera) of potential forensic importance in southern Brazil. Revista Brasileira de Entomologia 55: 333-347.

Vianna, E.E.S., Costa, P.R.P., Fernandes, A.L. \& Ribeiro, P.B. 2004 . Abundância e flutuação populacional das espécies de Chrysomya (Diptera, Calliphoridae) em Pelotas, Rio Grande do Sul, Brasil. Iheringia, série Zoologia 94: 231-234.
Watson, E.J. \& Carlton, C.E. 2003. Spring succession of necrophilous insects on wildlife carcasses in Louisiana. Journal of Medical Entomology 40: $338-347$.

Watson, E.J. \& Carlton, C.E. 2005. Insect succession and decomposition of wildlife carcasses during fall and winter in Louisiana. Journal of Medical Entomology 42: 193-203.

Wendt, L.D. \& Carvalho, C.J.B. 2009. Taxonomia de Fanniidae (Diptera) do sul do Brasil - II: novas espécies e chave de identificação de Fannia Robineau-Desvoidy. Revista Brasileira de Entomologia 53: 171206.

Zumpt, F. 1965. Myiasis in man and animals in the Old World. A textbook for physicians, veterinarians and zoologists. London, Butterworths, $267 \mathrm{p}$.

Received 19 December 2013; accepted 15 September 2014

Associate Editor: Gustavo Graciolli 